\title{
The study of ancient Egyptian fingerprints: preliminary remarks
}

\section{Matilde Borla' and Andrea Giuliano²}

I Egyptian Museum, Turin. Italy.

2 Interregional Department of the Scientific Police for Piedmont and Valle d'Aosta, Turin. Italy.

KEY WORDS: mummies, fingerprints, Scientific Police

\section{Abstract \\ Preliminary results of the scientific project on ancient fingerprints, born from the cooperation between the Egyptian Museum in Turin and the Department of the Scientific Police are discussed. Following the study on ancient fingerprints on terracotta ushabtis found by Ernesto Schiaparelli in Deir el-Medina, this study deals with the fingerprints of Egyptian mummies.}

The topic of this research is the study of ancient Egyptian fingerprints.

The study has been developed from cooperation between the Turin Egyptian Museum and the Forensic Police Department of Turin. The scientific investigation has been carried out by Dr. Matilde Borla, egyptologist of the Turin Egyptian Museum and by Chief Police Inspector Andrea Giuliano.

Regarding the observations of anthropological nature, we were honoured with the participation of the Department of Animal and Human Biology of Turin, which we thank very much for having kindly received us for this congress.

As far as fingerprints are concerned, we have to make a distinction between two classes of finds:

I. Archaeological finds (terracotta statues, ceramics and other clay material)

2. Anthropological finds (human mummies)

4 Our research started one year ago with archaeological finds.

The first step of the research concerned methodology, the technique of investigation: how to obtain fingerprints from ancient finds?

Obviously, because of conservation problems, not all modern techniques can be applied. The method we used followed four steps:

I. Preliminary macroscopical observation

2. Photos
3. Picture enlargement and digital elaboration of the pictures

4. Fingerprints study

We start by briefly describing the investigation carried out on archaeological finds: Egyptian shabtis, a class of funerary statues (Fig. 1).While studying and classifying some

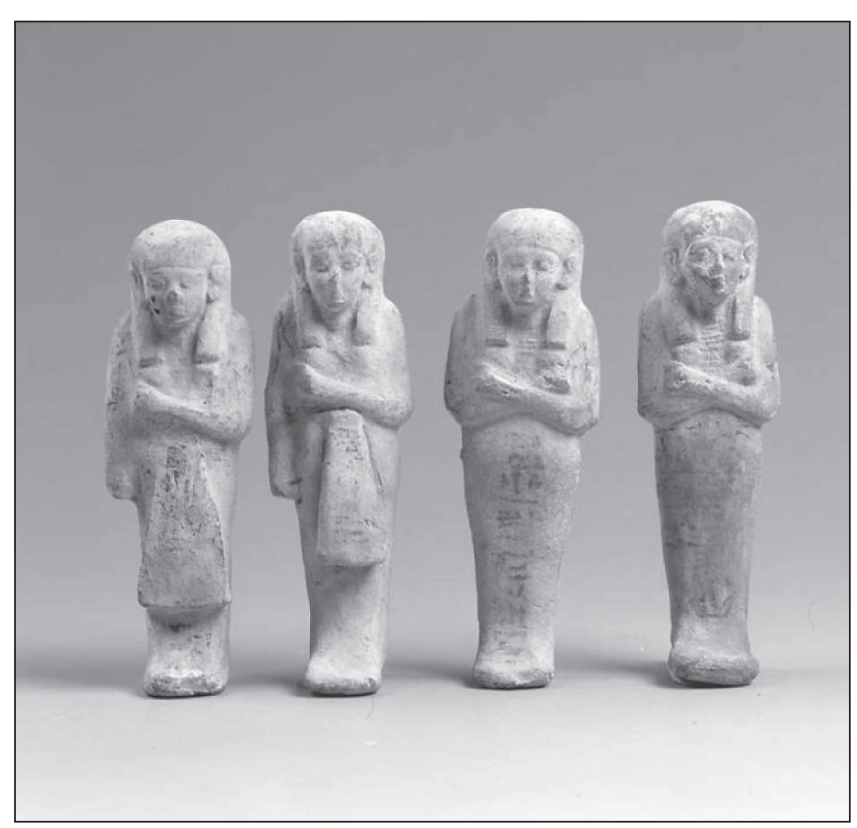

Fig. 1 - Funerary shabtis of Nespayherhat.

terracotta shabtis of an Egyptian priest of Amon named Nespayherhat from the Deir el-Medina necropolis excavated by Schiaparelli 1909, some lines on the back sides of the statues were observed.After a while it was realised that we were confronted by fingerprints (Fig. 2). Studies of the fingerprints, especially the identification of the fingers and their position on the object itself, let us understand how the craftsman worked with his hands in moulding the shabti with his left and right thumbs. Further result, from a methodological point of view, is the database of ancient fingerprints that we will put on line as soon as possible.

The second step of our research concerned anthropological finds. 


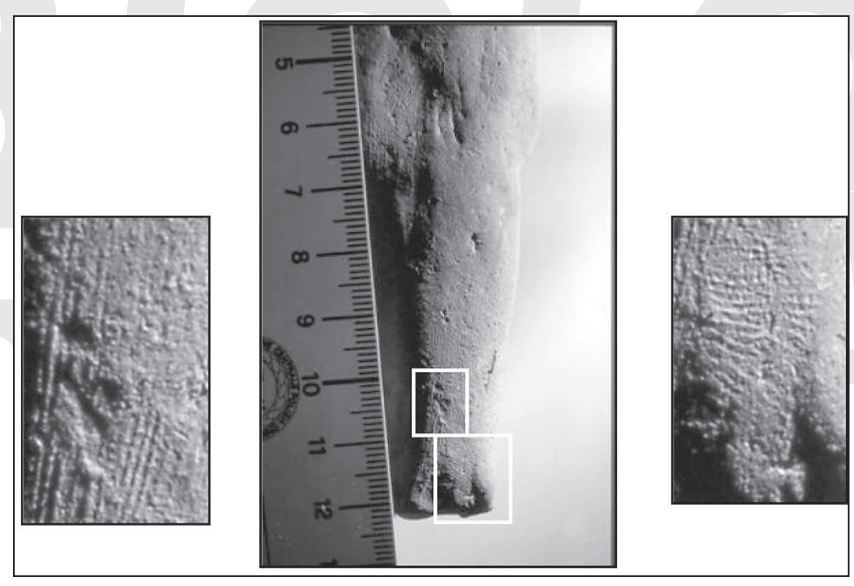

Fig. 2 - The back side of shabti S. 10354.

The Turin Egyptian Museum has 7I human mummies (most of them in storage). Some of these belong to the Drovetti collection, bought in 1824; others are the result of the excavations carried out by Schiaparelli, Farina and Marro in Egypt.

We should underline that only some of the mummies kept in Turin are unwrapped. Most of them are wrapped and, at the moment, we don't have the possibility of using them for our research.

Probably, in the future, we could utilise methods, that are not invasive and which would allow us to verify the state of conservation of fingerprints in order to study them.

Among the mummies that are unwrapped we selected Prov. 6I 0, 6II, 6I2, Suppl. 293, Suppl. 5056, 5060, C2256.

The test investigation started with both hands of a mummy from the Drovetti collection, Inventory number Cat. 2256 (Fig. 3). The left hand is wrapped. The right one is

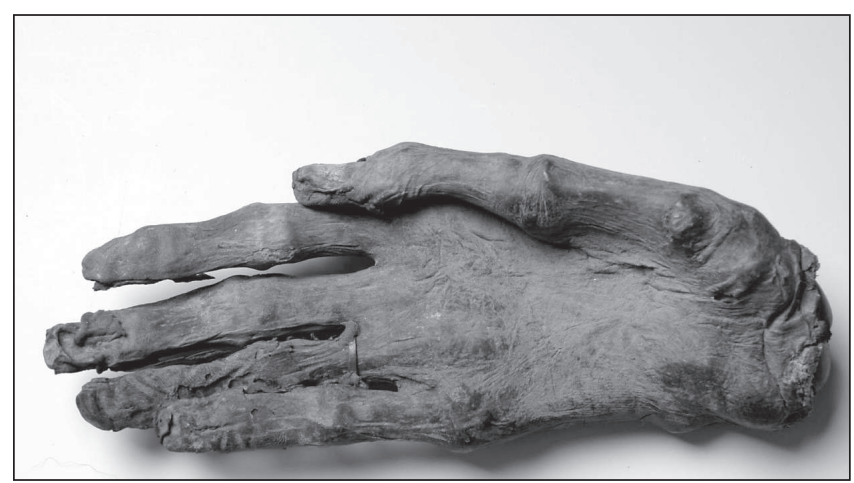

Fig. 3 - The right hand C. 2256.

unwrapped and bears very nice fingerprints. As we can see, the papillary drawing of the finger is better preserved in comparison with that of the palm region.

In correspondence with the finger, the sheaves of papillary lines are distinguishable and allow us to establish the correspondent fingerprint pattern (we call them basal, marginal and central).

I Let us observe each finger of the hand:

The forefinger (Fig. 4): is characterized by a scheme of the whorl type.

There are two visible deltas and the centre of the fingerprint is precisely determinable.
2 The middle finger unfortunately presents a partial epithelial exfoliation that does not presently allow us to establish the fingerprint pattern.

3 The ring finger (Fig. 4) has the papillary drawing (ridges) very well preserved. It is a whorl fingerprint pattern (like the forefinger). It is possible to determine, in a very simple manner, both the area of the deltas and that of the centre of the fingerprint.

4 The little finger: being partially wrinkly, it does not allow us to establish the fingerprint pattern with any certainty (we cannot establish a correspondence with fingerprint pattern).

For each finger we also looked for friction ridge characteristics (whose technical name is "minutiae"). These are observable in all the fingerprints. It is amazing that on the index and ring fingers the countersign of the features reached greater numbers than those habitually required for juridicial identification (I5-I7 features).

We close with the thumb: although the fingerprint is very well preserved, we are not able to identify it because of the position of the finger, turned down on the palm of the hand.

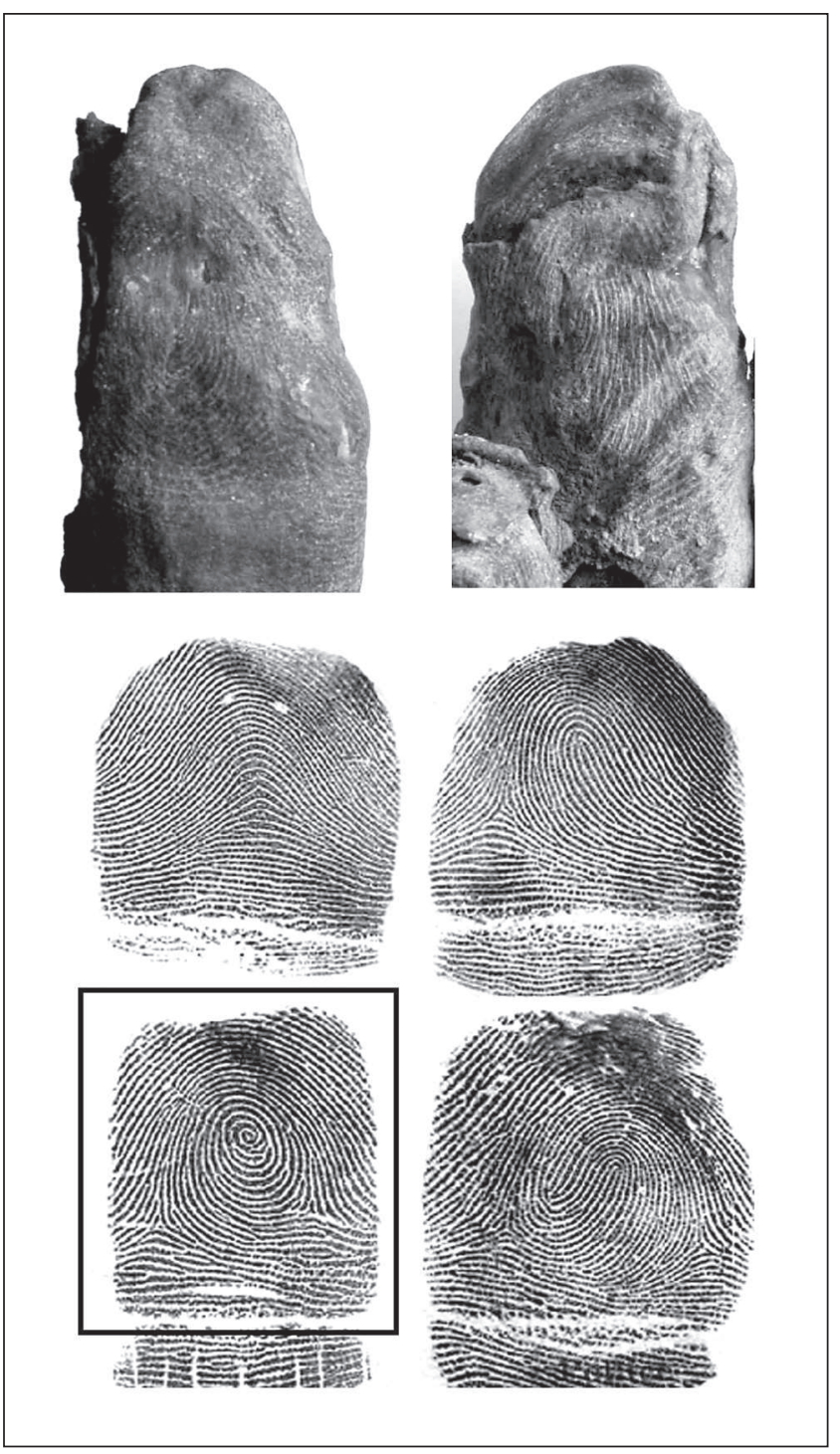

Fig. 4 - Left:The forefinger Right:The ring finger Whorl dactilary type. 
The difficulty in reading the thumb fingerprint brings us to a discussion related to the methods of obtaining fingerprints from ancient biological finds, a serious problem of conservation and one which requires non-invasive techniques.

A possibility that we would like to test, in order to obviate the problems of conservation and of anthropological finds decipherment specified above, is offered by the technique of radiological investigation using CT-scan.

This method, successfully used in the facial reconstruction of the mummy of Harwa (topic treated in the poster section), has never been used in the study of

\section{fingerprints.}

We would like to conclude by underlining what we can obtain from this research and a listing of our goals. An enormous numbers of intellectual, technological and financial resources are involved. Is this research really useful?

In our opinion the answer is positive because we could test a large number of innovative methods that will allow to:

I Provide a new forensic method for the identification of human remains, as for example in aircraft disasters.

2 Carry on studies on the variations of shape, of dimension and of composition of ancient fingerprints in order to improve our knowledge of their evolutionary development.

3 Contribute to research on the ancient populations and their evolution.

4 Deep observation of the skin of the mummies could offer some precious information to palaeoanthropologists.

Finally, using CT-scan technology, we will also be able to study the fingerprints of wrapped mummies. In this case we would be able to compare the characteristics of both hands.

\section{Literature Cited}

Alciati G. 1960."Sulla metodologia per lo studio dei rilievi cutanei palmari”, Rivista di Antropologia 47, pp. 89- 127.

Anelli S, Analisi dei dermatoglifi sulle cretule provenienti da Seleucia (Bagdad), Tesi inedita di laurea, a.a. 1996-1997.

Astrom P, Erikson S. 1980. Fingerprints and Archaeology, Goteborg. Aubert JF, Aubert L. 1974. Statuettes égyptiennes, chaouabtis, ouchebti, Paris.
Bonnevie K. 1924. Studies on Papillary Patterns of Human Fingers, Journal of Genetics 15, pp. I-III.

Camposano R,Argomenti di Polizia Scientifica. Direzione Centrale della Polizia Criminale, Servizio Polizia Scientifica, Roma.

Cummins H, Midlo C. 1926. "Palmar and Plantar Epidermal Ridge Configurations in European-Americans", American Journal Phys. Anthropology 9, pp. 47I-502.

Dzierzykray Rogalsky T, Grzeszyk Cz. 199I. Dermatoglyphes relevés sur les lampes de Kom-el-Dikka (Alexandrie), Cahiers de la Céramique égyptienne 2, pp. 125-128.

Fabretti A, Rossi F, Lanzone RV, Regio Museo di Torino.Antichità Egizie, Torino, I. I882, II I 888.

Floris G. 1974, Generalità sui dermatoglifi, in M. Masali (a cura di), Methods in Human Biology, Torino 1974, pp. 69-77.

Giuliano A. 2004. Dieci e tutte diverse. Studio sui dermatoglifi umani, Tirrenia Stampatori, Torino.

Gottarelli A, Proietti L,Vitali D. 1990. Analisi delle impronte digitali e della strategia di presa sulla ceramica a vernice nera, in Scienze in archeologia - II ciclo di lezioni sulla ricerca applicata in archeologia, 7-19 novembre 88, Siena, pp. 425-450.

Gualdi-Russo E. 1988. Dermatoglifi, in Facchini F. (a cura di), Evoluzione uomo e ambiente - Lineamenti di antropologia, Torino.

Invernizzi A, Papotti CM. 1991. Sealings and Fingerprints at Seleucia-on-the-Tigri, in KI. Schippmann, A. Herling, J.F. Salles (a cura di), Golf-Archäologie, pp. 33-43.

Kordel E, Janot F, Rapport d'étude lophoscopique de moulages d'empreintes digitales effectués sur des statuettes en terre cuite d'Apollonia, Lybie (inedito).

Olivieri L. 1963. Antropologia e Antropometria, Napoli.

Ponti G. 1999. Compendio di Criminologia, Milano.

Petrie WMF. 1935. Shabtis, ERA 57, London

Salis N. 200I. Position d'une population alpine (Vallouise) par rapport à l'étude des dermatoglyphes, Actes de l'Université Européenne d'Etè.

Schneider HD. 1977. Shabtis. An Introduction to the History of Ancient Egyptian Funerary Statuettes with a Catalogue of the Collection of Shabtis in the National Museum of Antiquities at Leiden, 3 vol, Leiden.

\footnotetext{
* Preliminary results have been published in: M. Borla, A. Giuliano, F. Janot, "Lo Studio delle Impronte Digitali Antiche e la Costituzione di un Archivio Internazionale dei Dermatoglifi dell'Egitto e del Mondo Antico. Risultati preliminari”, BSEG 25, 2002-03, p. 5-2I; M. Borla,A. Giuliano, “Una lente sulle impronte antiche", Archeologia Viva n 103, gennaio-febbraio 2004, p. 74-77.
} 